\author{
Marta Machowska \\ Instytut Etnologii i Antropologii Kulturowej \\ Wydział Historyczny \\ Uniwersytet im. Adama Mickiewicza w Poznaniu
}

\title{
Turystyka i niematerialne dziedzictwo kulturowe: przegląd szans i zagrożeń. Na przykładzie rzemiosła i rękodzieła tradycyjnego
}

\begin{abstract}
Streszczenie: Turystyka jest coraz prężniej rozwijającą się gałęzią gospodarki oraz ważnym zjawiskiem społecznym. Szczególnie wartko rozwija się turystyka kulturowa, która jest płaszczyzną spotkań turystyki i niematerialnego dziedzictwa kulturowego. Odpowiada potrzebom człowieka ponowoczesnego, poszukującego wrażeń i odmienności. Sama Konwencja UNESCO z 2003 roku w sprawie ochrony niematerialnego dziedzictwa kulturowego pomija temat turystyki. Przez specjalistów i osoby zajmujące się ochroną dziedzictwa jest ona odbierana jako zagrożenie, skutkujące komercjalizacją i utowarowieniem. Jednak turystyka może mieć również pozytywny wpływ na niematerialne dziedzictwo kulturowe, w tym na tradycyjne umiejętności rękodzielnicze. Tematem artykułu jest relacja między turystyką a niematerialnym dziedzictwem kulturowym, ze szczególnym uwzględnieniem rękodzieła i rzemiosła tradycyjnego. W tekście podjęta została próba wskazania wynikających z tego kontaktu szans i zagrożeń. Opisana na końcu tekstu tradycja koronkarska w Bobowej pokazuje, że mimo wielu zagrożeń, relacja ta nie musi pociągać za sobą wyłącznie negatywnych konsekwencji.
\end{abstract}

Słowa kluczowe: turystyka, niematerialne dziedzictwo, rzemiosło, rękodzieło

\section{Tourism and Intangible Cultural Heritage: a Review of Opportunities and Threats. The Case of Traditional Crafts and Handicrafts}

\begin{abstract}
Tourism is an important social phenomenon and a sector of economy that is developing more and more rapidly. It is especially cultural tourism that grows fast and also serves as a platform for the meeting of tourism and intangible cultural heritage. It meets the needs of the postmodern man who seeks excitement and diversity. The UNESCO Convention for the Safeguarding of the Intangible Cultural Heritage (2003) does not address the topic of tourism. From the point of view of researchers, it is regarded as a threat to intangible cultural heritage that may result
\end{abstract}


in its commercialization and commodification. However, tourism can also have a positive impact on intangible cultural heritage, including traditional handicraft skills. The topic of the paper is the relationship between tourism and intangible cultural heritage with particular emphasis on traditional crafts and handicrafts. The text is an attempt to show the positive and negative consequences of this contact and to demonstrate on the example of traditional lace-making in Bobowa that the relationship does not entail only negative consequences.

Key words: tourism, intangible cultural heritage, crafts, handicrafts

\section{Wstęp}

Turystyka jest ważną gałęzią gospodarki, która z każdym rokiem systematycznie się rozwija, wpływa na dochód państw oraz zatrudnienie. W Polsce udział gospodarki turystycznej w PKB kraju na przestrzeni lat 2007-2011 utrzymywał się na stosunkowo wysokim poziomie. W 2011 roku stanowił niecałe 5 procent PKB, generując ponad 760000 miejsc pracy [Raport o Stanie... 2013: 75, 80]. Według prognoz Światowej Rady Podróży i Turystyki znaczniki te mają się systematycznie podwyższać [https://www.wttc. org/-/media/files/reports/economic\%20impact\%20research/countries\%20 2015/poland2015.pdf].

Turystyka jest także istotnym zjawiskiem społecznym. Raport Ministerstwa Sportu i Turystyki wskazuje, że liczba turystów w Polsce zwiększa się. W 2011 roku 43 procent mieszkańców kraju w wieku powyżej piętnastu lat deklarowało udział w przynajmniej jednym wyjeździe turystycznym krajowym lub zagranicznym. W 2013 roku wskaźnik ten wzrósł do 56 procent [Janczak, Patelak 2014: 15].

Motywy, które kierują ludźmi przy podejmowaniu decyzji o wyjeździe, są różnorodne. Dla części z nich podstawowym celem podróży jest chęć powiększenia zasobów swojej wiedzy, także tej z zakresu niematerialnego dziedzictwa kulturowego. Takich turystów, chcących poznać coś nowego, w literaturze przedmiotu nazywa się turystami kulturowymi.

Szczególną zachętą dla wielu z nich, do podjęcia decyzji dotyczącej wyjazdu turystycznego, jest zakwalifikowanie przez specjalistów jakiegoś miejsca, obiektu bądź zjawiska jako wyjątkowych i godnych poznania. Opi- 
nie autorytetów odzwierciedlają oficjalne rejestry i atesty [Banaszkiewicz 2011: 12; Mikos von Rohrscheidt 2008: 53-54], jak na przykład wpis na Listę siedmiu cudów świata, Listę światowego dziedzictwa UNESCO lub od 2008 roku Listę niematerialnego dziedzictwa światowego UNESCO.

Turystyka może pociągnąć za sobą zarówno negatywne, jak i pozytywne skutki dla niematerialnego dziedzictwa kulturowego. W artykule podejmuję próbę wskazania szans i zagrożeń, jakie za sobą pociąga relacja między turystyką a specyficzną domeną niematerialnego dziedzictwa kulturowego jaką jest rękodzieło i rzemiosło tradycyjne. Na początku uwagę koncentruję na zdefiniowaniu turystyki, dziedzictwa kulturowego oraz rękodzieła tradycyjnego, między innymi w oparciu o Konwencję UNESCO z 2003 roku. W kolejnej sekcji staram się znaleźć konkretne powiązania między turystyką a tradycyjnymi umiejętnościami rękodzielniczymi i rzemieślniczymi. Następnie omawiam negatywne i pozytywne skutki relacji między turystyką a niematerialnym dziedzictwem kulturowym oraz istotną dla tego tematu kwestię autentyczności. W ostatniej części tekstu, odwołując się do tradycji koronkarskich w Bobowej, staram się zobrazować na konkretnym przykładzie skutki, jakie dla niematerialnego dziedzictwa kulturowego pociąga za sobą turystyka.

W artykule korzystałam z materiałów zebranych w czasie badań terenowych prowadzonych w Wielkopolsce, Małopolsce, na Lubelszczyźnie i Ziemi Lubuskiej w latach 2013-2014 wśród twórców ludowych¹. Mimo że głównym tematem tych badań byli sami twórcy oraz rękodzieło, to w wielu wywiadach rozmówcy odnosili się do turystyki. Dodatkowy materiał zebrałam prowadząc obserwacje na imprezach o tematyce rękodzielniczej: XVI Międzynarodowym Festiwalu Koronki Klockowej w Bobowej (2015 rok), Niedzieli Twórców w Parku Etnograficznym w Dziekanowicach (lata 2014-2015) oraz jarmarkach bożonarodzeniowym i wielkanocnym

1 Część badań realizowanych było w ramach projektu Atlas polskich strojów ludowych: kontynuacja prac wydawniczych, przeprowadzenie badań terenowych i kwerend źródłowych oraz cyfryzacja materiałów źródłowych i udostępnienie ich w Internecie finansowanego ze środków Ministerstwa Nauki i Szkolnictwa Wyższego w ramach Narodowego Programu Rozwoju Humanistyki, realizowanego w latach 2012-2015. Cytowane wywiady znajdują się w archiwum projektu. Więcej na temat badań: http://stroje.ptl.info.pl/. 
w Muzeum Rolnictwa i Przemysłu Rolno-Spożywczego w Szreniawie (lata 2014-2015).

\section{Definicja turystyki kulturowej i niematerialnego dziedzictwo kulturowego}

Turystyką nazwać możemy każdy przejaw ludzkiej mobilności, polegający na dobrowolnym wyjeździe z miejsca zamieszkania na co najmniej jedną dobę i mniej niż na rok [Mikos von Rohrscheidt 2008: 14]. Przez długie lata głównymi motywacjami podróżniczymi był relaks. Ukształtował się wtedy model wypoczynku polegający na spędzaniu czasu na plaży w nadmorskich kurortach, przeznaczonych wyłącznie do zaspokajania potrzeb turystów, odizolowanych od kultury, w której się znaleźli. Obecnie coraz większą popularność zdobywa turystyka nastawiona na rozrywkę, ekscytację i kształcenie [Kruczek 2009: 71]. Odpowiada to oczekiwaniom „Człowieka ponowoczesnego", permanentnie spragnionego nowych wrażeń [Bauman 1994: 30], który pragnie „zanurzyć się w oceanie kulturowej odmienności” [Banaszkiewicz 2012: 169]. Zadanie to spełnia rozwijająca się obecnie turystyka kulturowa, czyli:

[...] wszystkie grupowe lub indywidualne wyprawy o charakterze turystycznym, w których spotkanie uczestników podróży z obiektami, wydarzeniami i innymi walorami kultury wysokiej lub popularnej albo powiększenie ich wiedzy o organizowanym przez człowieka świecie otaczającym jest zasadniczą częścią programu podróży lub stanowi rozstrzygający argument dla indywidualnej decyzji o jej podjęciu lub wzięciu w niej udziału [Mikos von Rohrscheidt 2008: 31].

Czynnikiem odróżniającym turystykę kulturową od innych rodzajów turystyki, jest chęć powiększania zasobów wiedzy. Środkiem do poznania może być sztuka, muzyka, kuchnia, ale także uczestnictwo w miejscowych obrzędach i zwyczajach [Mokras-Grabowska 2009: 14]. Turystyka kulturowa powinna być moralna, to znaczy powinna dążyć do zachowania odwiedzanych miejsc i kultur w niezmienionym stanie [Buczkowska, Malchrowicz-Mośko 2012: 44]. W innym razie możemy mówić o turystyce 
pseudokulturowej oraz o turystach „kulturowych kanibalach” [Buczkowska b.d.]

Istotnym pojęciem dla omawianego przeze mnie tematu jest dziedzictwo kulturowe, szczególnie niematerialne. Pojęcie niematerialnego dziedzictwa kulturowego, mimo iż istniało w polskiej nauce przed ratyfikowaniem przez Polskę w 2011 roku Konwencji UNESCO z 2003 roku, upowszechniło się właśnie w pierwszej dekadzie XXI wieku. Wiąże się ono z szerszym pojęciem, jakim jest samo dziedzictwo oraz często zamiennie stosowanym terminem - tradycja.

Dziedzictwo to „coś, co dostajemy po przodkach, coś nam przynależnego, wreszcie coś, co jest kolejnym etapem w długiej historycznej ciągłości spadkobierców przeszłości” [Brzezińska, Jełowicki, Mielewczyk 2015: 20]. Termin dziedzictwo zawsze musi zostać doprecyzowany. W tym przypadku kluczową kategorią jest dziedzictwo kulturowe.

Dla Stanisława Ossowskiego dziedzictwo kulturowe wychodziło poza obręb kultury materialnej, a w swojej definicji skupił się on przede wszystkim na postawach emocjonalnych:

Na dziedzictwo kulturowe grupy społecznej składałyby się pewne wzory reakcji mięśniowych, uczuciowych i umysłowych, według których kształcą się dyspozycje członków grupy, ale żadne przedmioty zewnętrzne nie wchodziłyby w skład tego dziedzictwa [Ossowski 1966: 64].

Zdaniem Ossowskiego kluczowe nie jest zatem dziedziczenie przedmiotów, a doznania i przeżycia wywoływane przez te przedmioty, zgodne z dyspozycjami, które przekazywane są z pokolenia na pokolenie [Brzezińska, Jełowicki, Mielewczyk 2015: 20].

Rozważania nad niematerialną sferą dziedzictwa kulturowego w Polsce nie są nowością. Dawniej stosowano jednak inną terminologię na opisywanie tych zjawisk. Już w latach pięćdziesiątych $X X$ wieku Kazimierz Moszyński podzielił kulturę na materialną, symboliczną oraz duchową [Moszyński 1958]. Kultura materialna to dla Moszyńskiego świat artefaktów i fizycznych przedmiotów, natomiast kultura symboliczna i duchowa wiązały się z tymi zjawiskami, które są ulotne i często ciężko uchwytne, 
a jednocześnie stanowią istotną część dziedzictwa kulturowego [Brzezińska 2013: 133-136]. To właśnie te dwie sfery kultury - społeczna i duchowa - składają się na niematerialne dziedzictwo kulturowe [Brzezińska, Jełowicki, Mielewczyk 2015: 23].

W świetle samej Konwencji UNESCO z 2003 roku niematerialne dziedzictwo kulturowe oznacza:

praktyki, wyobrażenia, przekazy, wiedzę i umiejętności - jak również związane z nimi instrumenty, przedmioty, artefakty i przestrzeń kulturową - które wspólnoty, grupy, i w niektórych przypadkach, jednostki uznają za część własnego dziedzictwa kulturowego. To niematerialne dziedzictwo kulturowe, przekazywane z pokolenia na pokolenie, jest stale odtwarzane przez wspólnoty i grupy w relacji z ich otoczeniem, oddziaływaniem przyrody i ich historią oraz zapewnia im poczucie tożsamości i ciągłości, przyczyniając się w ten sposób do wzrostu poszanowania dla różnorodności kulturowej oraz ludzkiej kreatywności [http://niematerialne.nid.pl/].

W latach siedemdziesiątych XX wieku Jerzy Szacki wprowadził rozróżnienie między pojęciami: dziedzictwo i tradycja. W drugim, uaktualnionym wydaniu książki Tradycja uznał, że dziedzictwo jest bliższe pamięci kulturowej, bardziej bezrefleksyjne i niewartościowane [Szacki 2011: 18]. Tradycję wyróżnia emocjonalny stosunek, gdyż nie jest nią samo dziedzictwo grupy, lecz wszystko to, co w jej oczach uchodzi za dziedzictwo, niezależnie od stopnia swej „autentyczności” [Szacki 2011: 19]. Zgodnie z myślą Szackiego tradycja wiąże się z wyborem i wartościowaniem, niezależnie od stopnia autentyczności. Składają się na nią świadomie wyłaniane przez członków grupy elementy, uznane przez nich za ważne.

Z poglądem Jerzego Szackiego nie zgadzają się autorzy pierwszego tomu Atlasu niematerialnego dziedzictwa kulturowego wsi wielkopolskiej [Brzezińska, Jełowicki, Mielewczyk 2015]. Przyznają słuszność zaproponowanemu przez socjologa podziałowi na trzy sposoby rozumienia słowa „tradycja”: czynnościowe, przedmiotowe i podmiotowe. W podejściu czynnościowym nacisk kładziony jest na proces przekazu międzypokoleniowego, w przedmiotowym - interesujące są same treści poddane transmisji. Dla spojrzenia podmiotowego istotny jest „stosunek danego pokolenia do 
przeszłości, jego zgoda na dziedziczenie lub protest przeciwko niemu" [Szacki 2011: 102]. Natomiast sam podział na dziedzictwo i tradycję wprowadzony przez Szackiego, uznają oni za anachroniczny i niedostosowany do dzisiejszych czasów. Uzasadniając swoją postawę zauważają, że zarówno tradycja, jak i dziedzictwo, w myśleniu potocznym utożsamiane przede wszystkim z kulturą ludową, tracą obecnie na autentyczności i w tym kontekście zmniejsza się ich zasób. Miejsce to zajmują treści importowane z kultury miasta bądź ze świata [Brzezińska, Jełowicki, Mielewczyk 2015: 21]. W konsekwencji kurczącego się zasobu autentycznego dziedzictwa autorzy dochodzą do wniosku, że dziedzictwo kulturowe i tradycja zaczynają być pojęciami bliskoznacznymi lub nawet wymiennymi: „W naszej świadomości wszystko, co jest dla nas ważne, co pochodzi z przeszłości, jest dziedzictwem, czyli tradycją. To czego nie pamiętamy, nie mamy do tego stosunku, nie istnieje, nikt o tym nie wie (poza wtajemniczonymi specjalistami)" [Brzezińska, Jełowicki, Mielewczyk 2015: 22].

Jeśli przyznamy, że pojęcia tradycji i niematerialnego dziedzictwa kulturowego są bliskoznaczne bądź synonimiczne, musimy pamiętać o dwóch istotnych ich cechach: teraźniejszości i wariantowości. Oznacza to, że dziedzictwo (oraz tożsama z nim tradycja) nie jest niezmienne, lecz poddawane ciągłym reinterpretacjom. Pewne treści są przekazywane w nienaruszonej formie, inne usuwane i zastępowane nowymi. Jeszcze inne zaś przekazywane kolejnym pokoleniom w znacznie zmienionej formie. Dziedzictwo jest „teraźniejsze, co oznacza, że jest tylko naszym, bo przez nas (dzisiaj we współpracy ze specjalistami) stworzonym wariantem przeszłości” [Brzezińska, Jełowicki, Mielewczyk 2015: 23].

\section{Rzemiosło i rękodzieło tradycyjne w świetle Konwencji UNESCO} W 2011 roku Polska ratyfikowała Konwencję UNESCO w sprawie ochrony niematerialnego dziedzictwa kulturowego, dołączając tym samym do państw, które uznały swoje niematerialne dziedzictwo za ważny składnik kultury i tożsamości, zasługujący na ochronę na równi z dziedzictwem materialnym. Ustalenia Konwencji UNESCO z 2003 roku obejmują ochronę niematerialnego dziedzictwa, zapewnienie mu poszanowania, dążenie do wzrostu świadomości jego znaczenia przy międzynarodowej współpracy. 
Niematerialne dziedzictwo kulturowe odgrywa ważną rolę w życiu każdej społeczności, tworzy tożsamość i buduje poczucie wspólnoty, utrwala więzi społeczne i międzypokoleniowe [Jasiewicz 2013: 57]. Posiada także potencjał ekonomiczny i ma wpływ na rozwój regionu. Wskazuje, co jest ważne dla danej społeczności. Istotą Konwencji UNESCO nie jest utrwalenie niematerialnego dziedzictwa w niezmienionym stanie, lecz zapewnienie mu żywotności, uświadomienie jego znaczenia oraz zachęcenie depozytariuszy do jego kultywowania i przekazywania [Adamowski, Smyk 2013: 10].

Na potrzeby Konwencji wyodrębniono pięć domen niematerialnego dziedzictwa kulturowego. Zaliczają się do nich:

- tradycje i przekazy ustne, w tym język jako nośnik niematerialnego dziedzictwa kulturowego;

- sztuki widowiskowe;

- zwyczaje, rytuały i obrzędy świąteczne;

- wiedza i praktyki dotyczące przyrody i wszechświata;

- wiedza i umiejętności związane z rzemiosłem tradycyjnym.

Pierwsze cztery domeny nie budzą wątpliwości co do ich niematerialności. Natomiast rzemiosło i rękodzieło tradycyjne są zjawiskiem trudnym do skategoryzowania. Ręczne wytwarzanie przedmiotów użytecznych i artystycznych w ramach „przemysłu domowego” lokuje się między sferą materialną a niematerialną [Błachowski 1974: 200-208; Brzezińska 2010: 273]. Z jednej strony, produkt końcowy ma charakter materialny, z drugiej zaś umiejętności, dzięki którym został stworzony, należą jak najbardziej do sfery niematerialnej [Brzezińska, Jełowicki, Mielewczyk 2015: 20]. Dlatego też działania w ramach Konwencji nie powinny się skupiać na ochronie wyrobów, lecz na zachęcaniu twórców do kontynuowania prac, przekazywania umiejętności i wiedzy następcom, a członków danej społeczności przekonywać do podjęcia nauki.

Na Krajowej liście niematerialnego dziedzictwa kulturowego UNESCO, z zakresu rękodzieła i rzemiosła tradycyjnego, znalazł się haft kaszubski szkoły żukowskiej, umiejętność wytwarzania instrumentu i gry na kozie oraz perebory - nadbużańskie tradycje tkackie. W przypadku flisackich tradycji w Ulanowie, wnioskodawcy zdecydowali się objąć ochroną takie 
przejawy niematerialnego dziedzictwa, jak gwara, pieśni czy obrzędy flisackie, pomijając umiejętności wytwarzania łodzi. Wśród wpisów na wspomnianą listę niewiele jest zatem tych, odnoszących się do tradycyjnego rzemiosła i rękodzieła. Powodem takiego stanu rzeczy może być wspomniany fakt łączenia ich z materialną sferą kultury. Zapomina się natomiast o niematerialnym wymiarze tego dziedzictwa, jakimi są same umiejętności i tradycje, przekazywane z pokolenia na pokolenie.

\section{Turystyka w świetle Konwencji UNESCO}

W tekście Konwencji z 2003 roku problem turystyki nie został bezpośrednio podjęty. Art. 1. Konwencji traktuje o celach ochrony niematerialnej sfery kultury i, obok działań związanych z bezpośrednią ochroną i współpracą międzynarodową, wymienia również zapewnienie poszanowania niematerialnego dziedzictwa kulturowego wspólnot, grup i jednostek, a także wzrost świadomości znaczenia niematerialnego dziedzictwa kulturowego i zapewnienie wzajemnego docenienia.

Turystyka może stać się sposobem na powiększenie poszanowania dla elementów niematerialnego dziedzictwa kulturowego poprzez umożliwienie ludziom spotkania z odmienną kulturą. Niewykluczone, że efektem tego kontaktu będzie szacunek i wzrost świadomości znaczenia poznanego dziedzictwa. W czasie prowadzonych badań terenowych uczestniczyłam w warsztatach rękodzielniczych tkackich, hafciarskich oraz koronkarskich. Przed warsztatami uczestnicy określali wyroby rękodzielnicze jako ładne, jednak szczególnie zaczęli cenić je wtedy, gdy zauważyli, ile trudu należy włożyć w ich wykonanie. Wraz z nabywaniem umiejętności rękodzielniczych wzrósł szacunek członków grupy do konkretnego rzemiosła. Tak jak wcześniej ceny rękodzieła wydawały się być wygórowane, tak po warsztatach zostały zaniżone w stosunku do włożonej pracy i poświęconego im czasu. Podobną opinię wyrażali twórcy. Koronkarka z województwa lubuskiego w czasie rozmowy przyznała, że turyści na jarmarkach i imprezach folklorystycznych najczęściej kupują „drobiazgi”, które się prosto i szybko wykonuje, dzięki czemu są tanie. Większe wzory sprzedaje głównie osobom, które także zajmują się koronkarstwem, ponieważ one potrafią docenić wartość rękodzieła: „Najczęściej sprzedaję komuś, kto 
spróbował robić frywolitki, bo takie osoby znają wartość wyrobu" [koronkarka, Wilkowo, pow. świebodziński, woj. lubuskie, wrzesień 2014].

Konwencja przywiązuje dużą wagę do edukacji lokalnej i regionalnej oraz ochrony żywego, czyli cały czas przekazywanego i kultywowanego, dziedzictwa. Mówi o promocji oraz rewitalizacji poszczególnych jego elementów. Sama organizacja jaką jest UNESCO, tworzy rejestr przejawów dziedzictwa, czyli listę pilnej ochrony, listę reprezentatywną oraz rejestr dobrych praktyk. Wpis na którąkolwiek z nich nobilituje społeczności związane z danym dziedzictwem. Jak było już wspomniane, takie listy są zachętą dla turystów do odwiedzenia danego miejsca i jego poznania. Zainteresowanie turystyczne zjawiskiem kulturowym wpływa na świadomość depozytariuszy niematerialnego dziedzictwa kulturowego. Nie wszyscy uczestnicy kultury zdają sobie sprawę z jej wartości i unikalności. Czasami dopiero osoba z zewnątrz społeczności uświadamia im ten fakt [Banaszkiewicz 2011: 13]. Najczęściej są to specjaliści: etnografowie, folkloryści, muzealnicy. Jednak rolę taką mogą pełnić również turyści, których obecność będzie oznaką unikatowości zjawiska [Wieczorkiewicz 2003: 160].

Uzupełnieniem Konwencji UNESCO z 2003 roku są dyrektywy wykonawcze przyjęte w 2009 roku w Abu Dhabi, dotyczące efektywnej jej implementacji. Określono w nich warunki konieczne dla właściwego wypełnienia jej zapisów. Jak udowadnia Sławomir Ratajski, dopiero zapoznanie się z tymi dokumentami pozwala na pełne zrozumienie sensu Konwencji [Ratajski 2013: 21]. Same dyrektywy przestrzegają przed „nadużyciami dotyczącymi miejscowych tradycji oraz możliwościami zbytniej komercjalizacji i niezrównoważonej turystyki” [Ratajski 2013: 26], ponieważ może mieć to wpływ na autentyczność zjawisk. W dyrektywach postuluje się zrównoważony charakter rozwijającej się na bazie niematerialnego dziedzictwa kulturowego działalności komercyjnej, w tym turystyki.

\section{Związek turystyki z rękodziełem ludowym}

W kontekście turystyki kulturowej rękodzieło i rzemiosło tradycyjne mogą być atrakcyjne na kilku płaszczyznach, zarówno dla turystów, władz, jak i środowiska lokalnego. W Polsce za region przyciągający swoim dzie- 
dzictwem kulturowym największą liczbę turystów uważa się Podhale [Trebunia-Staszel 2014; Szpilka 2014]. Jednak także inne regiony promują swoje tradycje jako atrakcję turystyczną. Dla władz samorządowych takie działania mają cel marketingowy: skonstruowanie wizerunku regionu, przyciągnięcie inwestorów i turystów, stworzenie nowych miejsc pracy i zaplecza kulturalnego. Z perspektywy mieszkańców promocja własnej kultury może przyczynić się do ich aktywizacji oraz pomóc przy poszukiwaniu tożsamości indywidualnej oraz grupowej [Brzezińska 2014: 152-153].

Lokalne niematerialne dziedzictwo kulturowe może zostać rozpoznane przez turystów jako atrakcja, stając się tym samym walorem turystycznym. Zdaniem Justyny Mokras-Grabowskiej efektem takiego procesu będzie przejście od lokalnej kultury do turystycznego produktu kulturowego [Mokras-Grabowska 2009: 16]. Miejscowa kultura ulega wówczas procesowi komercjalizacji lub zaczyna być produktem na sprzedaż, funkcjonującym na zasadach rynkowych.

Jak zauważył Andrzej Szpociński obecnie uformowała się nowa wrażliwość historyczna, w następstwie której ludzie nie chcą poznawać świata intelektualnie, lecz zmysłowo [Szpociński 2006: 25-45]. Wraz z rosnącym zainteresowaniem rekonstrukcjami historycznymi, wzrosła potrzeba na rekonstrukcje etnograficzne: pokazy rzemiosł, warsztaty garncarstwa, plecionkarstwa, rekonstrukcja żniw i winobrania, wypiek chleba.

Rękodzieło i rzemiosło tradycyjne są przede wszystkim walorem takich gałęzi turystyki kulturowej, jak turystyka wiejska i agroturystyka. W ich przypadku turyści udają się - celem wypoczynku - na obszary mało zurbanizowane. Motywacją do podjęcia turystyki wiejskiej jest zapoznanie się z żywą kulturą lub reliktami dawnej kultury danego miejsca [Mikos von Rohrscheidt 2008: 103]. W ofertach turystycznych, proponowanych w turystyce wiejskiej i agroturystyce, znajdują się często pokazy twórczości ludowej oraz warsztaty dla dzieci i dorosłych. Są one atrakcyjną ofertą szczególnie dla mieszkańców miast [Burszta 2001: 176; Burszta 2008: 11], dla których z „sielskości i wizji świata ludowego stworzono [...] produkt" [Przewoźny 2014: 39-40]. Współczesny turysta, uczestniczący w tak sprofilowanych podróżach, jest zainteresowany odczuwaniem wrażeń, co odpowiada kondycji człowieka ponowoczesnego, zdiagnozowanej 
przez Zygmunta Baumana: „Turysta opuszcza dom w poszukiwaniu wrażeń. Wrażenia i opowieści o wrażeniach - oto jedyny łup, z jakim wraca, i jedyny na jakim mu zależy" [Bauman 1994: 30]. Szuka inności, wiedzy, ale przede wszystkim rozrywki. Z myślą o takich turystach rozwija się lokalny rynek usług, w tym budowanie produktów sieciowych, regionalnych i tradycyjnych, integrujących atrakcje, walory i subprodukty występujące na danym obszarze [Brzezińska 2014: 153]. W sieć produktów regionalnych mogą wchodzić również lokalne umiejętności i tradycje rękodzielnicze. Znajdują one wykorzystanie w takich gałęziach turystyki kulturowej, jak turystyka żywej historii (prezentacja dawnego życia codziennego lub świątecznego), turystyka kulinarna, hobbistycza, regionalna. Od momentu ratyfikowania Konwencji UNESCO z 2003 roku, rękodzieło ludowe, w przypadku wpisania go na Listę reprezentatywną niematerialnego dziedzictwa kulturowego UNESCO, może być także atrakcją dla turystyki dziedzictwa kulturowego. Jest to rodzaj turystyki kulturowej, sprofilowanej na kontakt z zabytkami, miejscami i zjawiskami powszechnie i oficjalnie uznanymi za dziedzictwo kulturowe świata, kraju albo regionu [Mikos von Rohrscheidt 2008: 53, 108, $130,155,161,166]$. Twórczość rękodzielnicza może być również walorem turystyki, której celem jest zetknięcie się z odległymi kulturami [Mikos von Rohrscheidt 2008: 140]. Andrzej Kowalczyk stosuje określenie „turystyka etnograficzna” bądź „folklorystyczna”, której celem jest poznawanie miejsc zamieszkiwanych przez różne społeczności (grupy etniczne, etnograficzne) i zapoznawanie się z ich żywą kulturą: zwyczajami, obrzędami, rzemiosłem [Kowalczyk 2008: 48].

\section{Zagrożenia związane z turystyką}

Tekst Konwencji w bezpośredni sposób nie traktuje o turystyce. Narodowy Instytut Dziedzictwa wymienia natomiast wzmożony ruch turystyczny jako zagrożenie dla dziedzictwa, obok globalizacji, migracji, urbanizacji, industrializacji, pogarszających się warunków ekonomiczno-społecznych i zaniku przekazu międzypokoleniowego: 
Niestety, zainteresowanie zewnętrzne może sprawić, że wartości ekonomiczne staną się najważniejszym powodem kultywowania dziedzictwa niematerialnego, które stanie się jedynie towarem na sprzedaż. $W$ ten sposób chęć zysku, skłonność do tego, by być postrzeganym jako atrakcja, może zniszczyć autentyczną potrzebę praktykowania elementów dziedzictwa. Dziedzictwo w takiej sytuacji może zostać celowo przetworzone dla usatysfakcjonowania i przypodobania się turystom, „ubarwione”, aby dodać mu cech estradowych; na przykład chęć sprzedaży pamiątek może doprowadzić do standaryzacji wzorów i słabej jakości wykonania, wynikających z masowej produkcji, mającej na celu maksymalizację zysków [http://niematerialne.nid.pl/].

Narodowy Instytut Dziedzictwa wspomina także o braku emocjonalnego zaangażowania i braku szacunku turystów wobec niematerialnego dziedzictwa kulturowego, co może zniszczyć atmosferę święta, utrudnić koncentrację na wykonywanym rytuale i zmienić sposób przeżywania danego obyczaju, zwyczaju lub uroczystości.

Obawa ta nie jest odosobniona, a zagrożenie dla specyficznej domeny niematerialnego dziedzictwa kulturowego, jaką stanowi twórczość ludowa, upatruje się w komodyfikacji, przekształceniu dziedzictwa w produkt „na sprzedaż”. Jednak, jak twierdzi Justyna Mokras-Grabowska, zjawisko komercjalizacji kultury, jako efekt procesów cywilizacyjnych, jest dzisiaj nieuniknione. Dawniej każdy człowiek i każda społeczność lokalna musiała wykazywać cechy samowystarczalności. Obecnie produkcja na własne potrzeby została ograniczona do minimum. Efektem postępu technologicznego jest zastąpienie pracy ręcznej, pracą maszyn. Rozwój nauki i kres myślenia magicznego pozbawił wiele zwyczajów i praktyk znaczenia symbolicznego. Mieszkańcy wsi nie potrzebują już kultury ludowej, w tym tradycji twórczych i umiejętności rękodzielniczych oraz ich materialnych efektów, które mogą przetrwać tylko w skomercjalizowanej formie [Mokras-Grabowska 2009: 17].

Utowarowienie ludowej kultury polskiej nie jest jednak ani zjawiskiem nowym, ani odosobnionym. Przywołać można opisany przez Johna Tylora przypadek kultury maoryskiej: inscenizowanych pokazów tańców i obrzędów organizowanych przez międzynarodowych touroperatorów 
[Tylor 2001]. W Polsce do utowarowienia i skomercjalizowania wyrobów kultury ludowej doszło jeszcze przed drugą wojną światową. Ważną rolę w tym procesie odegrało powołanie do życia instytucji zajmujących się upowszechnianiem wyrobów regionalnych, takich jak Towarzystwo Popierania Przemysłu Ludowego i Centrala Bazarów Kresowych w Wilnie. Idea ich powstania była zgodna z promowaną przez Saturnina Dąbrowskiego tezą, że „jedyną skuteczną formą ochrony sztuki ludowej jest zapewnienie jej rynku zbytu" [Korduba 2013: 79]. Działania te kontynuowała założona w 1949 roku Centrala Przemysłu Ludowego i Artystycznego (CPLiA), której zadaniem było ratowanie wiejskiej kultury. Jednak do dziś wielu badaczy zarzuca Cepelii i podległym jej spółdzielniom artystycznym, że w konsekwencji ich działań, szczególnie tych z lat siedemdziesiątych i osiemdziesiątych XX wieku, elementy kultury ludowej zostały zmodyfikowane, zestandaryzowane i uproszczone [Korduba 2013: 268-279]. Przetworzeniu uległy nie tylko wyroby materialne, ale także obrzędy, zwyczaje, śpiew i taniec [Burszta 1970: 17-18, Smolińska 2014: 228]. Czynnikiem wspomagającym ten proces była polityka państwa, dążąca do wykorzystania dziedzictwa kultury ludowej w celach ideologicznych [Mokras-Grabowska 2009: 17]. W efekcie możemy mówić o folkloryzmie, czyli cytowaniu wybranych elementów kultury ludowej poza kontekstem, w oderwaniu od pierwotnych znaczeń [Burszta 1989: 159].

Samo pojęcie folkloryzmu, wprowadzone na grunt polski przez Józefa Bursztę nie jako teoria, lecz słowo, za pomocą którego można uchwycić procesy modernizacyjne kultury ludowej i jej przekształcenia w ówczesnej sytuacji [Buchowski 2014: 140-141], wywołało wiele dyskusji [Burszta 1989: 161, 2009: 59, 68; Bukraba 1990: 167, 195; Smolińska 1999: 362, 2014; Sulima 1992: 181-183; Waliński 1977: 24; Waliński 1987: 90-91]. Z jednej strony, zauważano pozytywne aspekty folkloryzmu, ponieważ pozwalał na prezentację dziedzictwa kulturowego, z drugiej zaś krytykowano jego wtórność w stosunku do tradycyjnego folkloru i rozwijanie się w oparciu o wymogi widowiskowo-rozrywkowe oraz komercyjne: „kształtuje u odbiorcy nie tyle wiedzę, co zaledwie pewne wyobrażenie o folklorze" - pisano [Waliński 1977: 24]. Folkloryzm może być przynętą dla turystów ze względu na wszelkie ubarwienia i przetworzenia, które mają zapewnić 
cechy estradowe, „zamrażanie” dziedzictwa w czasie i prezentowanie turyście zgodnego z jego oczekiwaniami obrazu. Z tych samych przyczyn, oraz przez celową ingerencję, jest także zagrożeniem dla niematerialnego dziedzictwa kulturowego [Burszta 1970: 17-18; Smolińska 2014: 228].

Turystyka daje możliwość zarobku depozytariuszom niematerialnego dziedzictwa kulturowego. W przypadku rękodzieła czynnik ekonomiczny dotyczy przede wszystkim twórców ludowych. Wzbudza to jednak obawy wśród badaczy oraz osób i instytucji zajmujących się ochroną niematerialnej sfery kultury. Narodowy Instytut Dziedzictwa przestrzega, że wartości ekonomiczne mogą przeważyć nad wartościami symbolicznymi, które niesie kultywowanie dziedzictwa. Może to skutkować utratą autentyczności przez twórców i podejmowaniem działań skierowanych wyłącznie na usatysfakcjonowanie turystów, co przekłada się również na schematyzację i uproszczenie wzorów oraz na spadek jakości produktów. Oznacza to, że rękodzielnicy będą produkować rzeczy wyłącznie komercyjne, zatem takie, które będą dostosowane do wymogów estetycznych i cenowych turystów. By przyśpieszyć proces wytwórczy uproszczą formy oraz nie będą przykładać znacznej uwagi do dokładności pracy. Dodatkowo, proste formy, niewymagające wysokich umiejętności spowodują, że kunszt rękodzielniczy wraz z upływem czasu może zostać mocno ograniczony. W celu obniżenia ceny produktu końcowego, twórcy będą sięgać po tańsze materiały, które mają wpływ nie tylko na wygląd i trwałość produktu, ale również na sam procesy twórczy. Na przykład droższe nici hafciarskie nie są tak śliskie i nie plączą się tak mocno, jak ich tańsze odpowiedniki. Używanie zamienników generuje mniejsze koszty, jest jednak trudniejsze i może zniechęcać niedoświadczone osoby do dalszej nauki rękodzieła. Nie bez wpływu pozostaje konkurencja zewnętrzna, zwłaszcza tanich produktów, wykonywanych w krajach azjatyckich, nazywanych powszechnie, także wśród samych twórców, „chińszczyzną”: „Ta chińszczyzna to nas nie zaleje, a utopi! [...]. A te chińskie to do naszej kultury nie pasują" [hafciarka, Jarocin, pow. jarociński, woj. wielkopolskie, wrzesień 2013]. 


\section{Kwestia autentyczności}

Z powyższym problemem w bezpośredni sposób wiąże się kwestia autentyczności. Autentyczność - lub jej brak - stanowi często poruszany temat w kontekście relacji między turystyką a kulturą, natomiast utrata autentyczności jest jednym z głównych zagrożeń, będących efektem tego kontaktu. W pozbawionym autentyczności postmodernistycznym świecie, właśnie jej poszukiwanie ma motywować ludzi do podjęcia podróży [Boorstin 1992; MacCannell 2002]. Zdaniem Deana MacCannella turysta pragnie doświadczyć autentycznej kultury, którą odwiedza. Nie zadowala się wyłącznie sceną, na której rozgrywają się specjalnie zainscenizowane wydarzenia, lecz dąży do zajrzenia za kulisy [MacCannell 2002]. Daniel Boorstin twierdzi, że turysta nigdy nie doświadczy autentyczności, lecz jedynie zaaranżowanych, iluzorycznych i standardowych atrakcji, nazwanych „pseudowydarzeniami” [Boorstin 1992].

Kwestia autentyczności niematerialnego dziedzictwa kulturowego, wystawionego na kontakt ze wzmożonym ruchem turystycznym, budzi wątpliwości u wielu badaczy. Beata Hoffman zauważa, że turystyka pozbawia kulturę autentyczności, dążąc do wykreowania pseudoautentycznego jej wizerunku. Turystykę nazywa „wirusem turystycznej mistyfikacji”, który prowadzi do „nieuniknionej komercjalizacji kultury”, czego przejawem są proponowane turystom „towary z supermarketu kultury” [Hoffman 2012: 163-165]. Jednym z nielicznych pozytywów, jakie zdaniem autorki wynikają z kontaktu turystyki z dziedzictwem kulturowym jest fakt, że „dla tych społeczności [które stają się celem wypraw turystycznych - przyp. M.M.] turystyka może stać się jedynym motorem i mobilizatorem sięgania do zapominanych pokładów dziedzictwa kulturowego" [Hoffman 2012: 164]. Przedstawiona opinia sugeruje nadejście zmierzchu dziedzictwa kulturowego, bez względu na wartości symboliczne, tożsamościowe i integrujące, jakie niesie za sobą jego kultywowanie, dostrzegając jedyną nadzieję na to, że przetrwa ono w potencjale ekonomicznym.

Barbara Pabian wprowadza pojęcie mistyfikacji, które jest bliskie inscenizowanemu autentyzmowi Deana MacCannella, kreowaniu czy wymyślaniu kultury ludowej [MacCannell 2002: 143; Pabian 2014: 42]. Samo dziedzictwo autorka rozumie jako kulturę ludową, obejmującą różne formy życia środowisk lokalnych: 
folklor, obrzędowość, zwyczaje rodzinne i doroczne, sztukę ludową oraz całą sferę materialną, stanowiącą w przeszłości wewnętrznie spójny, autarkiczny system bytowania duchowo-materialnego, oparty na wspólnocie symbolicznej, semiotycznej i psychospołecznej jej uczestników [Pabian 2014: 39].

Dla autorki tak rozumiane dziedzictwo, nazywane także tradycją, jest tworem niezmiennym, a każda modyfikacja jest właśnie wspominaną mistyfikacją. W tym kontekście będzie nią tworzenie takiej wizji dziedzictwa, która nie jest zgodna z tradycją. „Zatraca się w ten sposób subtelna granica między pragnieniem zachowania i promocji regionalnego dziedzictwa, a tym, co wynika z pobudek wyłącznie komercyjnych" [Pabian 2014: 32]. Za przykład działań prowadzących do mistyfikacji podaje badaczka dekontekstualizację historycznego przekazu [Pabian 2014: 42]. W przypadku gospodarstw agroturystycznych będzie to hodowla strusi albo lam w polskich, wiejskich zagrodach. Za dekontekstualizację twórczości ludowej można uznać wykonywanie czynności mających znamiona codzienności w uroczystych strojach ludowych. W wyobraźni odbiorcy tworzy się wówczas obraz mieszkańców wsi, którzy zawsze, bez względu na okazję, zakładali odświętny ubiór, nawet do takich zajęć, jak tkanie, lepienie garnków czy wyplatanie koszy.

Sceptycyzm wobec autentyczności dziedzictwa kulturowego, przekazywanego turystom w czasie wczasów agroturystycznych wyraża wielu badaczy [Przewoźny 2014: 39; Malewska-Szałygin 2014: 70]. Zdaniem Wojciecha Burszty obraz wsi kreowany w gospodarstwach agroturystycznych jest nieautentyczny. Przedstawiają one bowiem sielską i całkowicie ahistoryczną wizję wiejskiego życia oraz kultury, co najlepiej widać na przykładzie Podhala [Burszta 2001: 176-181, 192-197]. Według Burszty wizja wsi budowana przez gospodarstwa agroturystyczne i przekazywana turystom jest tradycją wynalezioną [Burszta 2001: 176-181, Tradycja wynaleziona 2008].

Turystyka może mieć zatem negatywny wpływ na stan niematerialnego dziedzictwa kulturowego. Szczególnie, jeśli przyjmiemy za właściwe obiektywistyczne rozumienie autentyczności, którego istotę stanowi możliwość 
zweryfikowania jej w obiektywny sposób, za pomocą wcześniej przyjętych kryteriów. Najczęściej autentyczność taką stwierdzają znawcy w zakresie danej dziedziny [Nowacki 2013: 11-12]. W przypadku niematerialnego dziedzictwa kulturowego odpowiedzialni za orzekanie o autentyczności obiektywistycznej są specjaliści: etnolodzy, muzykolodzy, folkloryści.

Jednak takie pojmowanie autentyczności dziedzictwa zaprzecza idei zawartej w Konwencji UNESCO. Zgodnie z nią, kluczową rolę w ochronie niematerialnego dziedzictwa odgrywają same społeczności lokalne, które wnioskują o wpisanie go na listę reprezentatywną, akcentując tym samym to, co uważają za ważne i warte zachowania. Rola ekspertów i państwa została ograniczona przede wszystkim do działań informacyjnych, edukacyjno-ochronnych oraz wspomagających ochronę [Ratajski 2013: 25]. Ustalenia zawarte w Konwencji mają ponadto na celu ochronę żywego dziedzictwa, podtrzymywanie go i promowanie. Dziedzictwa, które mimo iż „tradycyjne”, to znaczy uznawane za dziedzictwo grupy przejęte od poprzednich pokoleń, ulega jednak modyfikacjom [Jasiewicz 2013: 58]. Konwencja UNESCO z 2003 roku nie dzieli zjawisk na „oryginalne”, „wtórne”, „autentyczne” czy „wynalezione”, ponieważ istotna jest ich akceptacja i możliwości pozytywnego oddziaływania na życie i świat wartości jednostek i współczesnych społeczności [Jasiewicz 2013: 56-57]. Jest to zatem bliższe autentyczności rozumianej w konstruktywistyczny sposób. W tej perspektywie autentyczność to twór relatywny, efekt społecznej konstrukcji: „decyduje o niej kontekst, w jakim usytuowany jest obiekt, i jest efektem porównań dokonywanych przez turystów pomiędzy ich oczekiwaniami a percepcją odwiedzanych miejsce" [Nowacki 2013: 12]. Jeżeli podmiot uzna dane zjawisko za autentyczne, to bez względu na opinie specjalistów takie ono jest. Autentyczność konstruktywistyczna może być nadana również po upływie pewnego czasu [Nowacki 2013: 12].

Z powyższymi sposobami rozumienia pojęcia autentyczności łączą się dwie drogi jej uwierzytelniana, wyodrębnione przez Erica i Scotta Cohenów, a bazujące na opracowanej przez Toma Selwyna koncepcji autentyczności zimnej i gorącej. Zgodnie z nią, autentyczność zimna odnosi się do opisu obiektywnych faktów dotyczących zwiedzanego obszaru, druga natomiast jest doświadczeniem podmiotu i powstaje na 
podstawie subiektywnego spojrzenia i krytycznej oceny odwiedzanego miejsca [Selwyn 1996]. W nawiązaniu do tej koncepcji, uwierzytelnianie zimne ma charakter jednorazowy i oficjalny, przyjmuje formę certyfikacji [Cohen, Cohen 2012]. Marek Nowacki jako przykład podaje wpisy na Listę światowego dziedzictwa UNESCO [Nowacki 2013: 14]. Uwierzytelnianie gorące ma charakter powtarzalny i nieformalny, a jego istnienie zależy od powtarzalnego uwierzytelniania. Jest to proces tworzenia, zachowania i wzmacniania autentyczności danego obiektu bądź zjawiska. W przeciwieństwie do zimnego uwierzytelniana, które cechuje stagnacja i skostnienie, uwierzytelnianie gorące ma charakter przekształcający [Nowacki 2014: 13-14].

Idea uwierzytelniania poprzez wpis na Listę reprezentatywną niematerialnego dziedzictwa kulturowego UNESCO odpowiada cechom uwierzytelniania zimnego. Jednak w treści samej Konwencji można znaleźć znamiona patrzenia na autentyczność z perspektywy konstruktywistycznej i uwierzytelniania gorącego. Uwzględnia ona bowiem fakt zmienności niematerialnej kultury, która podlega ciągłym modyfikacjom oraz istotę emocjonalnego zaangażowania i znaczenia symbolicznego (rola integrująca, tożsamościowa) dla kultywującej ją społeczności. Dodatkowo, autentyczność niematerialnego dziedzictwa kulturowego jest uwierzytelniana poprzez jego kultywowanie i przekazywanie.

\section{Turystyka wobec niematerialnego dziedzictwa kulturowego: wyłącznie zagrożenie?}

Ruch turystyczny może być zagrożeniem dla niematerialnego dziedzictwa kulturowego, chociaż prawdopodobny jest również jego pozytywny wpływ na tę sferę kultury: wywołanie poczucia dumy wśród kultywujących niematerialne dziedzictwo osób oraz stanowienie dodatkowego źródła dochodu dla rzemieślników i twórców. Jednak przyjmując za punkt odniesienia autentyczność obiektywistyczną i uwierzytelnianie zimne, turystyka w dużej mierze odbiera sprawczość, decyzyjność oraz kreatywność przedstawicielom lokalnych społeczności, czyli kontynuatorom niematerialnego dziedzictwa. Sprowadza się ich do roli odtwórców. 
Istnieje obawa, że depozytariusze dziedzictwa kulturowego, w tym twórcy ludowi, w jego kultywowaniu będą zauważać tylko korzyści materialne. Istotnie, w czasie prowadzonych przeze mnie badań wielu twórców przyznawało, iż sprzedaje swoje produkty turystom. Pomimo to nie traktują oni tego jako podstawowego źródła dochodu, gdyż zarobione w ten sposób pieniądze nie gwarantują utrzymania. Kierują się zapotrzebowaniem rynku turystycznego, jednocześnie nadal bardzo istotne pozostaje jednak ich własne poczucie estetyki:

Co z tego, że wyrzeźbię świętego Rocha, skoro ludzie nie chcą Rocha. Ludzie chcą czego? Papieża, świętego Franciszka, bo go rozpoznają. A świętego Wawrzyńca już nie. Więc rok temu sprzedałem ze czterech Franciszków. Jezus Frasobliwy się sprzeda, ale Chrzest Jezusa w Jordanie już nie. A co z tego, że przyjdzie pani jedna, druga i będą ręce załamywać, jakie to piękne. Robię rzeźbę po to, żeby mnie zachwycała. Mnie, a innych? Co z tego [rzeźbiarz, Witkowo, pow. gnieźnieński, woj. wielkopolskie, marzec 2014].

Twórcy przyznają, że tworzą dla własnej satysfakcji, wiedząc jednocześnie, że ich praca jest bardzo trudna do wyceniania: „To się w tygodniach liczy. [...] Wie Pani, ile to trzeba nadźgać tego? To jest praca niezastąpiona. Niewyceniona mówiąc szczerze. [...] Bo każda jest inna. Ja mam satysfakcję zrobić jakiś wzór, opracować" [hafciarka, Jarocin, pow. jarociński, woj. wielkopolskie, wrzesień 2013]. Lub wręcz nieopłacalna:

No ja po prostu niedawno zacząłem. Musiałem gospodarzyć ostro, żeby z czegoś żyć, a jeszcze poszła przecież córka na studia, to trzeba było finansować przecież, nie? [...] Teraz jak mam czas, bo mam już jakiś dochód stały. To zacząłem się tym bawić. I czuję w tym satysfakcję, raczej wypoczywam przy tej robocie, nie? Bo to jest w ogóle niedochodowa sprawa. Jaka to może być dochodowa, jak ja cały dzień jeden takie coś robię, taką tackę, to powiedzmy trzeba dwa dni robić i jak ktoś zechce kupić i mówi: „Ty chcesz trzydzieści złotych? To jest drogo”. I piętnaście złotych na dzień zarobię, jeszcze sznurki i materiały. To jest takie hobby raczej [plecionkarz, Dołhobrody, pow. włodawski, woj. lubelskie, lipiec 2013]. 
Są także tacy, którzy kultywują tradycję i pragną, by była przekazywana kolejnym pokoleniom. Osoby takie są świadome jej znaczenia dla kultury regionu i tożsamości jego mieszkańców - „żeby to nigdy nie zginęło” [pisankarka, Rogalinek, pow. poznański, woj. wielkopolskie, czerwiec 2014]. Niestety brak jest dużego zainteresowania kontynuowaniem tradycji przez młodych członków lokalnych społeczności: „Młodzi nie chcą tego robić. Młody woli pojechać do Holandii i zarobić na samochód" [plecionkarz, Dołhobrody, pow. włodawski, woj. lubelskie, lipiec 2013]. Dlatego plecionkarz z Nowego Holeszowa z żalem zauważył, że rzemiosło tradycyjne „raczej nie ma szans na przetrwanie. [...] Mówię, że to są rzeczy, które z czasem przestaną istnieć" [plecionkarz, Nowy Holeszów, pow. włodawski, woj. lubuskie, lipiec 2013]. Co więcej, niektórzy z nich spotykają się z brakiem zrozumienia i szacunku ze strony lokalnej społeczności w stosunku do rękodzieła, którym się zajmują:

Często spotykam się z szyderstwem, kpiną z tego, co robię. Aczkolwiek mnie to nie zraża, ja jak to mówię, ja zawsze lubię mieć i robić coś, czego nie robią inni. [...] To nie jest, że robię na warsztacie, żeby się z tego utrzymać. Tylko dla przyjemności. To jest pasja [tkaczka, Dubeczno, pow. włodawski, woj. lubelskie, lipiec 2013].

Zainteresowanie turystów rzemiosłem i rękodziełem tradycyjnym może pozytywnie wpłynąć na jego odbiór w lokalnej społeczności, która dostrzeże, że jej własna kultura, ciesząca się zainteresowaniem zewnętrznym, jest warta kultywowania i szacunku. Oddziaływać to może także na pozycję społeczną samych twórców, którzy zostaną docenieni oraz zmotywowani do pielęgnowania tradycji rękodzielniczych. Co więcej, przy braku zainteresowania młodego pokolenia dziedzictwem, jego dowartościowanie może pomóc w znalezieniu osób chętnych do nauki tradycyjnych umiejętności rękodzielniczych, zarówno pochodzących z miejscowego środowiska, jak i spoza niego. Jest to o tyle ważne, że transmisja treści, w tym przypadku umiejętności rękodzielniczych, jest warunkiem przetrwania tradycji [Szacki 2011: 102]. Koronkarka z Jarocina zauważyła, że w czasie imprez turystycznych, zarówno w miejscu swojego zamieszkania, jak i poza 
nim - w Krakowie lub w Kazimierzu Dolnym - spotyka wiele osób, które zafascynowane jej rękodziełem, rozpoczynają u niej kurs. Zatem, gdyby nie imprezy turystyczne, na których twórczyni się prezentuje, osoby te prawdopodobnie nie podjęłyby się nauki techniki koronkarskiej. Dzięki takim wydarzeniom tradycyjne umiejętności rękodzielnicze - na przykład koronkarstwo - zostają docenione.

Stanisława Trebunia-Staszel przekonuje, że turystyka nie musi wykluczać poszanowania dla kultury, w tym dla niematerialnego dziedzictwa kulturowego. Odwołując się do przykładu górali podhalańskich twierdzi, że chociaż ich działania są ukierunkowane na rynek turystyczny, szanują oni swoje dziedzictwo i są z niego dumni. Możliwość odniesienia korzyści ekonomicznych może zmotywować młodych ludzi do podjęcia nauki gry na instrumencie lub wykonywania rękodzieła. Mimo że motywacja jest ekonomiczna, pozwala ona przetrwać tradycji i umożliwia jej transmisję. „Jest to już wszystko bardziej pod turystykę, choć z drugiej strony dobrze, bo dzięki temu uczą się grać. Jak kto umie połączyć tradycję z komercją, to wtedy jest dobrze, ale jak tylko dla komercji, to jest to już zatracenie" [Trebunia-Staszel 2014: 285].

Jak wspomniano powyżej, czasami twórcy wykorzystując tradycyjne umiejętności rękodzielnicze sięgają po nowe wzornictwo. Przykładem będzie słynna już bielizna z Koniakowa czy modne etui do telefonów i laptopów z motywami ludowego haftu. Sami rękodzielnicy zauważają jednak, że umiejętności techniczne, niezbędne do ich wykonania, są takie same, jak do produkcji serwety albo obrusu. Zmianie ulega wzór. W czasie badań często spotykałam się z opinią, iż z technicznej perspektywy nie ma różnicy między wykonywaniem serwety i wzoru współczesnego. Nauczenie się pewnej techniki pozwala na lawirowanie między wzorami tradycyjnymi a nowymi formami przygotowanymi dla współczesnego odbiorcy. Różnica polega na tym, że produkty przeznaczone na rynek turystyczny w formie pamiątek są przede wszystkim mniejsze, stąd wynika ich szybsze wykonywanie. Zdaniem Magdaleny Banaszkiewicz pamiątka to „miniatura rzeczywistości” oraz „materialna forma zjawiska niematerialnego" [Banaszkiewicz 2012: 175-176], dlatego powinna odzwierciedlać umiejętności i kunszt rękodzielnika. Niektórzy twórcy są dumni z tego, że 
obok odtwarzania ciągle tradycyjnych wzorów mogą stworzyć coś nowego i oryginalnego. To pozwala im wykazać się kreatywnością, dzięki której, w ich odczuciu, przestają być odtwórcami, a mogą być uznawani za prawdziwych twórców. Jest to także ich sposób na aktywne uczestniczenie w kulturze, sprzeciw wobec skonwencjonalizowanym formom i wzorcom [Brzezińska 2009: 167].

\section{Bobowa: turystyka i rękodzieło}

Bobowa - niewielkie miasteczko w Małopolsce, w powiecie gorlickim - znane jest przede wszystkim osobom zainteresowanym koronkarstwem. To niespełna trzytysięczne miasto słynie z wyrobu koronki techniką klockową, polegającą na krzyżowaniu, przekręcaniu i przeplataniu nitek nawiniętych na specjalne klocki - podłużne szpulki - przymocowane na wałki [Bezielich 1997: 89]. Nie wiadomo dokładnie, kiedy i kto nauczył bobowskie kobiety tej umiejętności. Sami mieszkańcy uważają, że koronka jest produkowana w Bobowej od zawsze. W XIX wieku miejscowa dziedziczka rozpowszechniła te umiejętności, ucząc bobowianki koronkarstwa [Kroh 2014: 17]. W 1866 roku fakt istnienia tradycji koronkarskich w Bobowej opisał w wychodzącym we Lwowie „Dzienniku Literackim” Szczęsny Morawski. W czasach Polskiej Rzeczypospolitej Ludowej koronkarki-chałupniczki dostarczały swoje wyroby do powołanej w 1949 roku Spółdzielni „Koronka” i Cepelii. Umiejętności rękodzielnicze były przekazywane instytucjonalnie, w działającej od 1899 roku Zawodowej Szkole Koronkarskiej (od 1950 roku jako Państwowa Zasadnicza Szkoła Koronkarska) oraz nieformalnie, w rodzinach.

Klasa koronkarska działała w Zespole Szkół Zawodowych w Bobowej do 1999 roku, kiedy to zamknięto ją z powodu braku zainteresowania wśród młodzieży. Był to bezpośredni skutek rozwiązania Spółdzielni „Koronka”, potencjalnego pracodawcy absolwentów specjalizacji koronkarskiej. Po likwidacji klasy zabrakło instytucji, która wspomagałaby przekazywanie miejscowego dziedzictwa kolejnym pokoleniom. W takiej sytuacji potrzebna była inna organizacja, która wzmocniłaby przekaz tradycji. Zadania tego podjęli się pracownicy Centrum Kultury i Promocji Gminy Bobowa oraz członkowie powołanego do życia w 1994 roku Stowarzyszenia Twór- 
czości Regionalnej. Zarówno Centrum, jak i Stowarzyszenie organizują kursy koronkarskie w Bobowej, dla mieszkańców miasta i gminy, ale też w innych regionach Polski: „Zawsze uważałem, że po pierwsze szkolić. Edukacja. Skoro nie ma klasy - kursy. Skoro jest z kim, to z dziećmi na początku" [prezes Stowarzyszenia Twórczości Regionalnej, Bobowa, pow. gorlicki, woj. małopolskie, lipiec 2014]. Kursy zaczęły prowadzić także niektóre rękodzielniczki. Jedna z nich otworzyła gospodarstwo agroturystyczne „Koronkarnia”, w którym oferuje kursy koronkarskie. Jej działalność łączy w sobie turystykę z nauką rękodzieła tradycyjnego, i cieszy się zainteresowaniem turystów z Polski oraz z zagranicy (Wielkiej Brytanii, Japonii, Hiszpanii). Aby zachęcić mieszkańców gminy do kultywowania dziedzictwa, a także by dać im możliwość pokazania swoich umiejętności rękodzielniczych, od lat dziewięćdziesiątych XX wieku zaczęto organizować konkursy, które z czasem, w 2000 roku, przekształciły się w organizowany do dziś Międzynarodowy Festiwal Koronki Klockowej [Brzezińska 2010: 276].

Festiwal ten przyciąga z całego świata turystów zainteresowanych rękodziełem, szczególnie koronką klockową. Na kolejną edycję, w październiku 2015 roku, do Bobowej przyjechały reprezentacje dwunastu krajów Europy. Oprócz tego małopolskie miasteczko gościło także polskich turystów. Festiwal cieszy się stosunkowo dużym zainteresowaniem, chociaż nie jest imprezą masową. Tym, co wyróżnia przybywających na niego turystów jest zainteresowanie rękodziełem, w szczególności koronką klockową ${ }^{2}$. W czasie festiwalu organizowane są pokazy twórczości, mody, warsztaty, wystawy i wykłady. Ogłaszane są także wyniki konkursu koronkarskiego. Na potrzeby turystów otwarto w Bobowej sklep z koronkami oraz materiałami potrzebnymi do ich wyrobu ${ }^{3}$. Proponowane w sklepie produkty są różnorodne: od niewielkich i niedrogich form (gwiazdki, zajączki), do bardziej skomplikowanych i droższych serwet oraz obrusów. Z Bobowej

2 Do Bobowej przyjeżdżają jednak nie tylko turyści nastawieni na rękodzieło tradycyjne, lecz również pozostali, zwiedzający okolice. Szczególnie, że Bobowa jest nie tylko stolicą polskiej koronki klockowej, ale dawniej była również ważnym centrum chasydyzmu. Do dziś pielgrzymują tam wyznawcy judaizmu.

3 Działa on także jako sklep internetowy. 
można także wysłać kartę pocztową z motywem koronki. W Centrum Kultury i Gminy Bobowa stworzono galerię, w której prezentowane są wyroby rękodzielnicze mieszkanek Bobowej, a zatrudniona w Centrum koronkarka może zaprezentować swoje umiejętności zainteresowanym. Od 2008 roku na płycie rynku stoi fontanna przedstawiająca koronkarkę przy pracy (powszechnie nazywaną przez bobowian Zosią), a w 2015 roku na ścianie Centrum Kultury odsłonięto mural z motywem bobowskiej koronki. $Z$ inicjatywy przedstawicielki młodego pokolenia koronkarek planowane są także działania mające na celu zebranie starych wzorów od mieszkanek miasta i okolicy, w celu ich odtworzenia i zaprezentowania na wystawie:

\begin{abstract}
Chcę odzyskać stare wzory, tutaj z Bobowej, bo panie mają przepiękne wzory. One mają wzorniki w szafach schowane, nie chcą ich dać, ale mają i są to wzory, które myszy zjadają, wyglądają nieraz strasznie. [...] I mam nadzieję, że dadzą mi te wzory, ja przeprowadzę cykl zajęć, żeby odrysować te wzory, zachować je. Później postaram się jakoś je przekonać, żeby mi dały oryginały, oprawić je w ramy i zrobić z nich wystawę, a z tych przerobionych wzorów wydać taki album z opisem wszystkich wzorów bobowskich, tradycyjnych. Żeby to nie zginęło [koronkarka, Bobowa, pow. gorlicki, woj. małopolskie, lipiec 2014].
\end{abstract}

Umiejętności i tradycja wyrobu koronki klockowej są istotne dla lokalnej społeczności. Jak pokazują daty opisanych wyżej przedsięwzięć, są one stosunkowo niedawne. Bobowa i jej mieszkańcy identyfikują się z tradycjami koronkarskimi, które pomagają tworzyć poczucie wspólnoty. Mimo iż od ponad piętnastu lat w lokalnej szkole nie istnieje klasa koronkarska, przekaz umiejętności rękodzielniczych jest żywy, a nauka dobrowolnie podejmowana. W czasie badań rozmawiałam między innymi z uczniem szkoły podstawowej, którego mama zapisała na kurs koronkarski na jego prośbę. Jednak przekaz tradycji nie odbywa się wyłącznie instytucjonalnie, lecz również nieformalnie, w rodzinach. Zatem transmisja międzypokoleniowa jest żywa.

Turystyka w Bobowej wydaje się nie wpływać negatywnie na stan niematerialnego dziedzictwa kulturowego. Zewnętrzne zainteresowanie miejscowym rękodziełem poskutkowało większym przywiązaniem do 
tradycji, zaczęto podejmować wiele działań na rzecz jej kultywowania i promowania. Przedsięwzięcia te są zarówno inicjatywami odgórnymi, inicjowanymi przez władze lokalne, ale także - a może przede wszystkim - przez społeczność lokalną, skupioną w Stowarzyszeniu Twórczości Regionalnej. Jego członkowie chcą chronić i przekazywać umiejętności koronkarskie kolejnym pokoleniom oraz promować je zarówno w Polsce, jak i na świecie. Dlatego też w ostatnim czasie podjęli kroki, których efektem ma być wpisanie bobowskiej koronki klockowej na Krajową listę niematerialnego dziedzictwa kulturowego UNESCO.

\section{Podsumowanie}

Główny tematem artykułu jest relacja między niematerialnym dziedzictwem kulturowym a turystyką. Wzmożony ruch turystyczny może skutkować negatywnymi konsekwencjami. Najczęściej obawa skierowana jest w stronę utowarowienia, schematyzacji i uproszczenia dziedzictwa. Obawy te nie są bezzasadne. Jednak, jak pokazują badania prowadzone wśród twórców ludowych, wielu z nich nie traktuje rzemiosła i rękodzieła tradycyjnego jako podstawowej formy zarobku i przyznaje, że jest to pasja, nieopłacalna z ekonomicznego punktu widzenia. Mimo iż niektóre produkty dostosowują oni do gustu odbiorcy, to równie ważne jest dla nich ich własne poczucie estetyki.

Istotą Konwencji w sprawie ochrony niematerialnego dziedzictwa kulturowego UNESCO z 2003 roku jest jego ochrona, co nie oznacza, iż ma być ono zachowane w niezmienionym stanie. Wraz z przekazem dokonuje się modyfikacja treści, jednak szczególnie istotny jest emocjonalny stosunek członków kultywującej je wspólnoty oraz wartość symboliczna. Łączy się to z koncepcją autentyczności konstruktywistycznej i gorącego sposobu jej uwierzytelniania. $Z$ tej perspektywy istotą uwierzytelniania dziedzictwa nie jest jednorazowe stwierdzenie jego autentyczności przez zewnętrzny autorytet, lecz proces ciągłego i wielokrotnego jej potwierdzania poprzez kultywowanie.

Przykładem społeczności, w której tradycje twórcze są nadal przekazywane z pokolenia na pokolenie, zarówno za pomocą instytucji kulturalno-oświatowych, jak i wewnątrz rodzin, jest Bobowa. To małe miasteczko, 
w którym od 2000 roku organizowany jest Międzynarodowy Festiwal Koronki Klockowej, przyciągający szczególnie turystów zainteresowanych rękodziełem i koronkarstwem, a także innych, którzy odwiedzają region. Podejmowane tam działania nie są jednak motywowane wyłącznie czynnikiem turystycznym, mimo że są atrakcjami turystycznymi. Inicjowane są z myślą o samych mieszkańcach Bobowej i okolic, którzy identyfikują się z tradycjami koronkarskimi miasta, budując na ich podstawie własne poczucie tożsamości.

\section{Bibliografia}

\section{Adamowski Jan, Smyk Katarzyna}

2013: Niematerialne dziedzictwo kulturowe - teoria i praktyka. [W:] Niematerialne dziedzictwo kulturowe w Polsce i jego ochrona. Red. J. Adamowski, K. Smyk. Lublin-Warszawa, s. 9-17.

\section{Banaszkiewicz Magdalena}

2011: Pamiątki turystyczne - w poszukiwaniu tożsamości. „Turystyka Kulturowa", nr 4, s. 4-16.

2012: Pamiątki turystyczne - miniatura czy karykatura dziedzictwa kulturowego? „Studia Etnologiczne i Antropologiczne”, t. 12, s. 167-178.

\section{Bauman Zygmunt}

1994: Dwa szkice o moralności ponowoczesnej. Warszawa: Instytut Kultury.

\section{Bazielch Barbara}

1997: Koronkarstwo. [W:] Piękno użyteczne czy piękno ginące. Informator o realizacji programu Ministerstwa Kultury i Sztuki „Ginące Zawody”. Red. B. Kopczyńska-Jaworska, M. Niewiadomska-Rudnicka. Łódź, s. 89-102.

\section{Błachowski Aleksander}

1974: Skarby w skrzyni malowanej, czyli o sztuce ludowej inaczej. Warszawa: Ludowa Spółdzielnia Wydawnicza.

\section{Boorstin Daniel}

1992: The Image: A Guide to Pseudo-Events in America. Nowy Jork: Vintage Books.

\section{Brzezińska Anna Weronika}

2009: Specjaliści od kultury ludowej? „Nauka”, nr 3, s. 155-172. 
2010: Wakacje z koronką. Oferta kształcenia w zakresie rękodzieła (wybrane przykłady). [W:] Handemade. Praca rąk w postindustrialnej rzeczywistości. Red. M. Krajewski. Warszawa, s. 272-278.

2013: Reifikacja dziedzictwa kulturowego w świetle Konwencji UNESCO z 2003 roku. „Nauka”, nr 1, s. 109-128.

2014: Różne światy kultury ludowej - perspektywa teoretyczna a działania praktyczne. [W:] Kultura ludowa. Teorie, praktyki, polityki. Red. B. Fatyga, R. Michalski. Warszawa, s. 133-154.

\section{Brzezińska Anna Weronika, Jełowicki Arkadiusz, Mielewczyk Wojciech}

2015: Atlas niematerialnego dziedzictwa kultrowego wsi wielkopolskiej. T. 1. Założenia, metodyka, cele. Szreniawa: Muzeum Narodowe Rolnictwa i Przemysłu Rolno-Spożywczgo w Szreniawie.

\section{Buchowski Michał}

2014: "Mały Wielki Człowiek”: Józef Burszta i związane z nim zagadki badawcze. [W:] Od etnografii wsi do antropologii współczesności. Tom dedykowany pamięci Profesora Józefa Burszty w setną rocznicę urodzin. Red. W. Dohnal. Poznań, s. 127-138.

\section{Buczkowska Karolina}

b.d.: Czy możliwa jest etyczna turystyka kulturowa?. „Post-turysta”. http:// post-turysta.pl/artykul/czy-mozliwa-jest-etyczna-turystyka-kulturowa [ostatni dostęp: luty 2015].

\section{Buczkowska Karolina, Malchrowicz-Mośko Ewa}

2012: Etyczne dylematy turystyki kulturowej. „Turystyka Kulturowa”, nr 12, s. $42-55$.

\section{Bukraba Izabella}

1990: Kultura ludowa na co dzień. Warszawa: Instytut Kultury.

\section{Burszta Józef}

1970: Folkloryzm w Polsce. [W:] Folklor w życiu współczesnym. Materiały z ogólnopolskiej sesji naukowej w Poznaniu w 1969. Red. B. Linette. Poznań, s. 9-29.

\section{Burszta Wojciech}

1989: Od folkloru lokalnego do „postfolkloryzmu” narodowego. „Konteksty. Polska Sztuka Ludowa", nr 3, s. 158-164.

2001: Asterix w Disneylandzie. Zapiski antropologiczne. Poznań: Wydawnictwo Poznańskie.

2008: Kultury ludowej już nie będzie. Rozmawiał Łukasz Grzymisławski. „Gazeta Wyborcza", 8-9 marca, s. 11. 
2009: Od mowy magicznej do szumów popkultury. Warszawa: Wydawnictwo SWPS „Academica”.

\section{Cohen Eric, Cohen Scott}

2012: Authentication: Hot and Cool. „Annals of Tourism Research”, no 39 (3), pp. 1259-1314.

\section{Hoffman Beata}

2012: Turystyka etniczna a doświadczenie kulturowej inności. „Studia Etnolo-

\section{Isański Jakub} giczne i Antropologiczne", t. 12, s. 153-166.

2005: Autentyczność przyjemności. Autentyczność pamiątki turystycznej. [W:] Kultura przyjemności. Rozważania kulturoznawcze. Red. J. Grad, H. Mamzer. Poznań, s. 131-144.

\section{Janczak Katarzyna, Patelak Krzysztof}

2014: Uczestnictwo Polaków w wyjazdach turystycznych w 2013 roku Łódź. http://www.msport.gov.pl/statystyka-turystyka/uczestnictwo-polakow-wwyjazdach-turystycznych-w-2013-roku [ostatni dostęp: grudzień 2015].

\section{Jasiewicz Zbigniew}

2013: Przedmiot i funkcje Konwencji o ochronie niematerialnego dziedzictwa kulturowego. Spojrzenie etnologa. [W:] Niematerialne dziedzictwo kulturowe w Polsce i jego ochrona. Red. J. Adamowski, K. Smyk. Lublin-Warszawa, s. 51-64.

\section{Korduba Piotr}

2013: Ludowość na sprzedaż. Towarzystwo Popierania Przemysłu Ludowego, Cepelia, Instytut Wzornictwa Przemysłowego. Warszawa: Fundacja Bęc Zmiana, Narodowe Centrum Kultury.

\section{Kowalczyk Andrzej}

2008: Współczesna turystyka kulturowa. [W:] Turystyka kulturowa. Spojrzenie

\section{Kroh Antoni} geograficzne. Red. A. Krawczyk. Warszawa, s. 36-49.

2014: Wesołego Alleluja Polsko Ludowa, czyli o pogmatwanych dziejach chłopskiej kultury plastycznej na ziemiach polskich. Warszawa: Wydawnictwo "Iskry".

\section{Kruczek Zygmunt}

2009: Między atrakcją a pułapką turystyczną. Dylematy turystyki kulturowej XXI wieku. [W:] Kultura i turystyka, razem ale jak. Red. A. Stasiak. Łódź, s. $71-80$. 


\section{MacCannell Dean}

2002: Turysta. Nowa teoria klasy próżniaczej. Przeł. E. Klekot, A. Wieczorkiewicz. Warszawa: Warszawskie Wydawnictwo Literackie MUZA SA.

\section{Malewska-Szałygin Anna}

2014: Kultura ludowa - aktualność pojęcia. [W:] Kultura ludowa. Teorie, praktyki, polityki. Red. B. Fatyga, R. Michalski. Warszawa, s. 69-70.

\section{Mikos von Rohrscheidt Armin}

2008: Turystyka kulturowa. Fenomen, potencjał, perspektywy. Gniezno: KulTour.pl.

\section{Mokras-Grabowska Justyna}

2009: Możliwości rozwoju turystyki kulturowej obszarów wiejskich w Polsce. „Turystyka Kulturowa”, nr 1, s. 14-31.

\section{Moszyński Kazimierz}

1958: Człowiek. Wstęp do etnografii powszechnej i etnologii. Warszawa: Instytut Historii Nauki Polskiej Akademii Nauk.

\section{Nowacki Marek}

2013: Jakość i autentyczność: czy jedno wyklucza drugie? [W:] Kultura i turystyka - miejsca spotkań. Red. B. Krakowiak, A. Stasiak, B. Włodarczyk. Łódź, s. 9-28.

\section{Ossowski Stanisław}

1966: Więź społeczna i dziedzictwo krwi. Warszawa: Państwowe Wydawnictwo Naukowe.

\section{Pabian Barbara}

2014: Folkloryzm i mistyfikacja w kulturowej działalności gospodarstw agroturystycznych - nieformalny sposób przekazywania wiedzy o kulturze ludowej. „Turystyka Kulturowa”, nr 9, s. 32-45.

\section{Przewoźny Witold}

2014: Jakie są współczesne przejawy kultury ludowej? Fragmenty wywiadu przeprowadzonego przez Justynę Dobrowińską i Dorotę Płuchator. [W:] Kultura ludowa. Teorie, praktyki, polityki. Red. B. Fatyga, R. Michalski. Warszawa, s. 39-40.

\section{Raport o Stanie...}

2013: Raport o Stanie Gospodarki Turystycznej w latach 2007-2011. Warszawa: Ministerstwo Sportu i Turystki. 


\section{Ratajski Sławomir}

2013: Koncepcja ochrony dziedzictwa niematerialnego w Konwencji UNESCO. [W:] Niematerialne dziedzictwo kulturowe w Polsce i jego ochrona. Red. J. Adamowski, K. Smyk. Lublin-Warszawa, s. 21-34.

\section{The Tourist Image...}

1996: The Tourist Image: Myths and Myth Making in Tourism. Ed. T. Selwyn. Chichester-New York: Wiley.

\section{Smolińska Teresa}

1999: Współczesna twórczość ludowa. Zastój czy rozwój? [W:] Folklorystyczne i antropologiczne opisanie świata. Księga ofiarowana Profesor Dorocie Simonides. Red. T. Smolińska. Opole, s. 361-367.

2014: $\quad$ Wręgu inspiracji badawczych Profesora Józefa Burszty: od folkloru do folkloryzmu. [W:] Od etnografii wsi do antropologii współczesności. Tom dedykowany pamięci Profesora Józefa Burszty w setną rocznicę urodzin. Red. W. Dohnal. Poznań, s. 203-234.

\section{Sulima Roch}

1992: Słowo i etos. Szkice o kulturze. Kraków: Zakład Wydawniczy FA ZMW "Galicja”.

\section{Szacki Jerzy}

2011: Tradycja. Warszawa: Wydawnictwo Uniwersytetu Warszawskiego.

\section{Szpilka Kuba}

2014: Lud tatrzański. [W:] Kultura ludowa. Teorie, praktyki, polityki. Red. B. Fatyga, R. Michalski. Warszawa, s. 223-250.

\section{Szpociński Andrzej}

2007: O współczesnej kulturze historycznej Polaków. [W:] Przemiany pamięci społecznej a teoria kultury. Red. B. Korzeniowski. Poznań, s. 25-42.

\section{Tradycja wynaleziona}

2008: Tradycja wynaleziona. Red. E. Hobsbawm, T. Ranger. Przeł. M. Godyń, F. Godyń. Kraków: Wydawnictwo Uniwersytetu Jagiellońskiego.

\section{Trebunia-Staszel Stanisława}

2014: Współczesne oblicza kultury regionalnej Podhala. [W:] Kultura ludowa. Teorie, praktyki, polityki. Red. B. Fatyga, R. Michalski. Warszawa, s. $251-288$.

\section{Tylor John}

2001: Authenticity and Sincerity in Tourism. „Annals of Tourism Research”, no 28 , pp. 7-26. 


\section{Waliński Michał}

1977: Folklor i folklorystyka. Uwagi na marginesie definicji. „Literatura Ludowa” nr 4/5, s. 3-26.

1987: Lubelska rozmowa o folkloryzmie (głos w dyskusji). „Literatura Ludowa”, nr 4/6, s. 87-92.

\section{Wieczorkiewicz Anna}

2003: Prawdziwe pamiątki: kwestia autentyczności w antropologii turystyki. „Kultura i Społeczeństwo”, nr 2, s. 145-177.

\section{Strony internetowe}

http://niematerialne.nid.pl/ [ostatni dostęp: luty 2015].

http://www.koronkarnia.eu/ [ostatni dostęp: grudzień 2015].

http://stroje.ptl.info.pl/ [ostatni dostęp: maj 2016].

https://www.wttc.org//media/files/reports/economic\%20impact\%20research/countries\%202015/poland2015.pdf [ostatni dostęp: styczeń 2016]. 